\title{
23 The nexus of procurement and sustainability
}

\author{
Reflection of the limits and \\ opportunities of product labels, \\ using the example of the \\ Forest Stewardship Council
}

\author{
Uwe Sayer and Nina Griesshammer
}

\section{Introduction}

The Forest Stewardship Council (FSC) established a set of rules on how forest management should be done in an ecologically and socially responsible way in the nineties. The idea was (and is) to use market tools such as certification and labels to encourage better forest management practices through demand driven by retailers and consumers. The underlying concerns, at that time, were the constant loss of forests and the maintenance of a relevant renewable source of timber and re fibre. Over the years, FSC has grown to a global system with around 200 Mio. ha of forests FSC certified and more than 38.000 companies associated worldwide. While FSC steadily improved upon its system and is perceived as one of the most trusted brand around responsible forest management worldwide, the nexus of a sustainability label remains. Products carrying a sustainability label (for example on forestry) stand for responsible procurement and wood or fibre product whereas a lot of basic fundamental remain open and unaddressed through the label such as sustainable production in processing or resource efficiency. While this becomes a growing global concern, this chapter reflects this nexus and formulates roles for various groups.

\section{Certification and labels in a changing environment}

While markets and consumer recognition of FSC grew steadily over the last years - up to 50\% in Germany (prompted, EMNID 2019), expectations and perception on certification and labels also changed.

In the late nineties, certification systems were expected to change the conditions for the production of goods worldwide significantly. Certification contributes to defined requirements for use of resources and/or requirements on production processes worldwide. However new challenges need to be addressed by innovative ways of production and consumption. These challenges are climate change, loss of biodiversity and the pollution of ecosystems, water and soils, use of pesticides and fertilisers through a global intensification of land-use systems. 
The growing market relevance and consumer recognition of certification systems and labels led to a reaction from competing market players resulting in various labels used in all sectors. Consumer protection organisations in Germany describe this process as a 'jungle of labels'. They have thus generated tools and platforms to help consumers distinguish between the meanings of the existing labels. Consequently, the media continually evaluates if labels do deliver what they aimed for and if they have a benefit for society. It is remarkable that the evaluation of labels is mostly not based on their own missions and values, but includes more current challenges of production. Some of those aspects may be far beyond current scopes of the related labelling-systems such as climate change and production intensification. As a consequence, the gap between expectations and the reality of systems like FSC acting in a complex, constantly shifting market combined with rapidly changing environmental conditions becomes bigger and bigger. Solutions are not easy to create and are picked up in the following chapter.

\section{The concept of the FSC system}

One of the founding ideas of FSC was (and is) a balance between economic, social and environmental aspects in forestry. As a result, FSC developed a 3-chamber-system giving all those aspects equal decision power. Sustainable management needs to integrate social and environmental values in their operational work far beyond what is usually understood as legal or acceptable.

To achieve balance, FSC has its members divided into three chambers: an economic, a social and an environmental chamber. In relevant decisions, all chambers have the same voting rights, and if needed because of the objection of a whole chamber, there is veto power. So according to FSC standard development processes for sustainable forestry need to follow this basic decision principle of considering all three chambers. Examples are international or national board decisions, member decisions or national standard-setting processes.

Primarily, FSC is responsible for forest management. The basis for this is FSC forest standards with national adaptions. After approval by FSC, forest enterprises have to use these standards as a basis for their forest management if they aim for an FSC certification. Independent certification bodies verify the compliance of forest owners with FSC requirements on a yearly basis.

FSC standards ask for:

- compliance with legislation;

- the establishment of consolidated management plans;

- special attention to environmental issues such as the use of pesticides, identification and special treatment of highly valuable and often sensible ecosystems, special treatment of forests along water lines, enhancement of biodiversity through setting aside forest areas;

- $\quad$ safeguards for working conditions in forests; 
- $\quad$ compliance with ILO conventions (ILO n.d.); and

- concepts to address unsolved land-use conflicts through FPIC (United Nations 2013).

After a successful audit, forest enterprise can label and sell their products as FSC certified. In the following processing and trading chain, all companies buying and selling certified materials need to be FSC certified if they want to use the FSC claim. As a consequence, they need to be compliant with the technical requirements for processing and trading of FSC certified materials (Chain of custody certification or COC certification). These technical requirements mainly address the physical product such as assembling, reassembling in new packaging formats, mixing with recycling or non-certified materials, among others. The intention of these COC certificates is mainly that FSC claims on products are correct.

\section{New FSC dimensions in processing and trade}

A vast variety of environmental and social questions such as recyclability, efficient resources, health questions in production, safe working conditions or fair salaries are not fully covered by COC certification of most environmental and social production labels.

On social issues, FSC in recent years decided to request compliance with minimum social requirements in COC certificates. FSC certified companies in the supply chain must make sure that work is done in compliance with ILO conventions. This global process still has some outstanding and unresolved questions for the implementation and affects around 50.000 FSC certified companies throughout all supply chains worldwide.

On environmental issues, there are also some minimum requirements requested by FSC-companies who want to mix not-certified materials to FSC-certified products. From the very beginning, discussions arose allowing mixing of FSC certified materials with recycling fibres of non-certified materials, particularly in large scale fibre-based industry processes such as pulp, paper or panels. In 1997 first policies have been published (FSC policy for Percentage-Based Claims) in which mixing of wooden materials was allowed under certain conditions. Conditions like continually increasing the FSC certified parts as well as safeguarding minimum environmental and social requirements for the non-certified parts. In the meantime, this concept has evolved into the global concept of Controlled Wood (CW). In this concept, FSC clearly defines unacceptable practices for non-certified wood sources which cannot be mixed with FSC certified materials and need to be avoided by companies (FSC 2017).

These are:

- $\quad$ illegally harvested wood;

- wood harvested in violation of traditional and human rights; 
- wood harvested in forests in which high conservation values (HCVs) are threatened by management activities (HCVs are areas particularly worthy of protection);

- wood harvested in forests being converted to plantations or non-forest use; and

- $\quad$ wood from forests in which genetically modified trees are planted.

Besides evaluating the wood streams from FSC certified materials, companies usually need to evaluate their whole wood supply with the controlled wood categories to produce FSC mix-products.

\section{Changes in production and trade through the FSC approach}

One fundamental concept used by FSC is the demand or the market-driven approach: The more FSC products are requested in markets, the more forest enterprises have market incentives to certify their forests and sell FSC products.

This has worked pretty well in the last 20 years in Germany based on the fact that relevant partners support FSC publicly and generate credibility. In Germany, FSC is supported by most of the well-recognised environmental organisations such as WWF or NABU (German affiliate of birdlife) as well as the big Labour Unions (IG BAU, IG Metall). Internal global evaluations clearly show that a strong reputation, a trusted brand and credibility are the most relevant aspects for companies to work with FSC followed by global coverage, expertise and efficiency. Based on FSCs balanced 3-chamber approach, social and environmental organisations know that their views are properly reflected in FSCs regulations. As a result, they actively support FSC as a system which helps to implement better social and environmental standards in global forestry and also demonstrates credibility towards society. Utilising FSC in the corporate sector incorporates this credibility into businesses when they sell or produce FSC products. Due to the governance structure, the support from credible partners and then the collaboration with the corporate sector, FSC products are vastly present in German markets covering most of the existing wood and fibre sectors.

\section{Prominent examples of transforming markets through demand}

Not only the private corporate sector but also the public procurement sector needs to address concerns around responsible sourcing. With the growing relevance of forest certification schemes, various governments decided to incorporate certification as requirements in the public procurement protocols. In Germany, FSC was mentioned as a possible verification of responsible sourcing for wooden products in public procurements starting in 2007 until today. 
In growing markets, the supply situation for FSC material is the limiting factor, but still, companies hesitate to formulate strong procurement policies since they could be publicly denounced. The reasons are that procurement policies are strong tools that demonstrate social and environmentalcommitments. If they are not carefully phrased and properly implemented, they have been interpreted as unambitious and as green-washing. At the same time procurement policies are powerful tools for corporate companies to communicate mid- and long-term goals for specific products.

In the paper and wood sector, there are prominent examples where companies publicly state their expectations towards suppliers for FSC certified wood and paper. Examples are:

- $\quad$ Lidl (Lidl Deutschland 2018): Publication of a position paper requesting all fresh-fibre in food packaging, household and tissue articles changed to Recycling or FSC until the end of 2018. Until 2020 expansion to all textiles, garden articles, furniture, toys, decoration articles, media, stationery, tools and instruction manuals. These sourcing requirements are embedded in a strategic frame of saving resources, the increase of recycled materials and the use of certified fresh fibres.

- Aldi 2018: Aldi North and Aldi South published a timber sourcing policy. Aldi North is explicitly requesting FSC certified wood if products are sourced in risk countries.

- $\quad$ EDEKA (EDEKA 2019): Announcement to shift sourcing of wood, paper and tissue to sustainable sources with Blue Angel or - in case of fresh fibre - to FSC certified sources. On packaging and Edeka owned brands, this was already implemented by the end of 2017 .

- OTTO (Otto Group 2019): As part of the CR strategy 2020 FSC certified catalogue paper is planned to be increased to $60 \%$ by 2020 and furniture to $100 \%$ by 2025 .

- IKEA (IKEA 2018): Public policy for 100\% FSC certified wood or recycling by 2020 .

\section{FSC's impacts on the ground}

With growing relevance, there are growing concerns and critical questions on systems like FSC: Are the aims reached and does the system deliver what it promises consumers through its products? Answers are not always easy to give.

Within national standards like the German FSC standard for forest management, it is comparably easy to phrase what the standard requires from forest owners. Relevant examples in Germany are regulations on tree species composition, set aside areas, definition and treatment of high conservation areas, biotope wood, skid trails, safer working conditions, and minimum salaries (including for external subcontractors). Through analysis of corrective actions from the audit, it can be evaluated which issues arise in Germany forest 


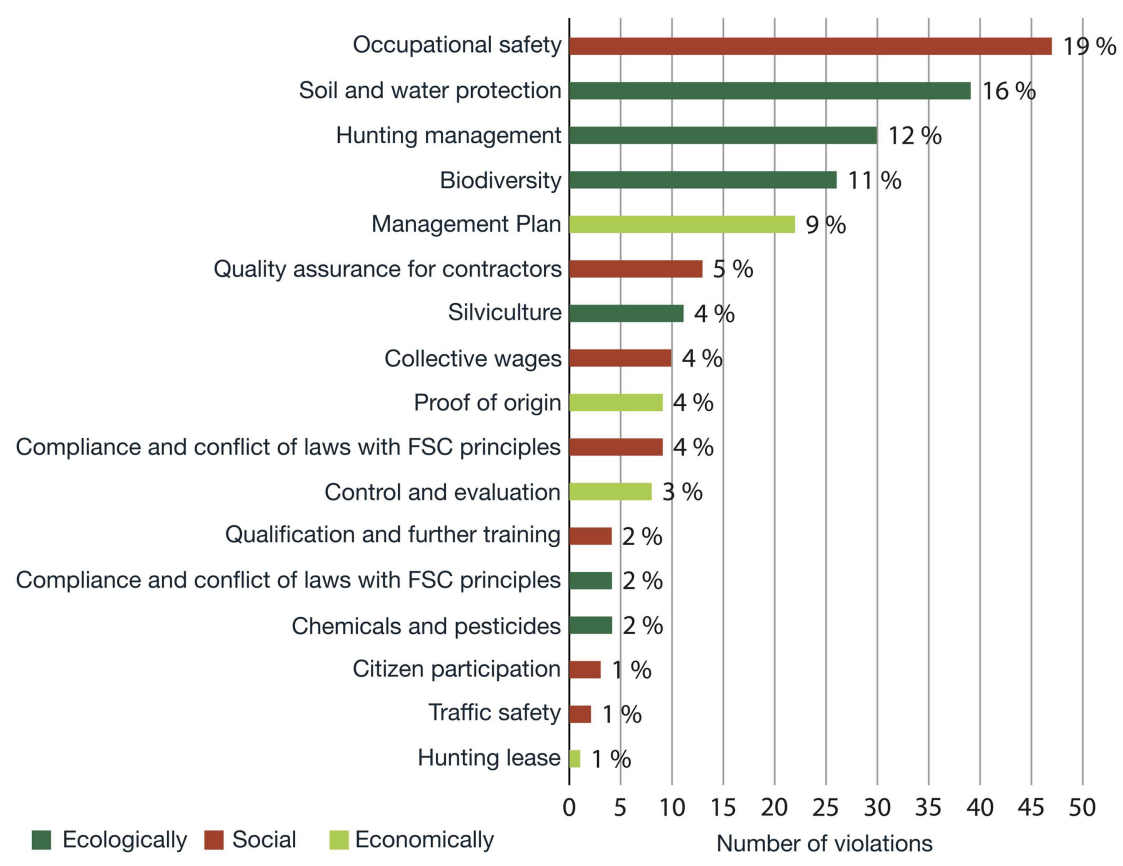

Figure 23.1 Distribution of the analysed corrective action requests divided into different categories, shown as percentages. Issues of corrective action requests through the FSC certification towards German FSC-certified forest enterprises and their relevance/ranking.

enterprises. Most relevant issues are corrections in safety equipment for woodworkers and issues around soil, water, hunting and biodiversity (Strasser \& Litschel 2017).

Besides these indirect approaches, there are scientific studies evaluating the impact of FSC. Usually, scientific studies are not easily accessible and are difficult to understand for people outside the scientific world. At the same time, the role of science is to work independently within defined and accepted methods on issues delivering answers to relevant questions of our time. The number of studies evaluating FSC worldwide with scientific approaches is limited but continuously growing. Many studies conclude that FSC has positive impacts on relevant questions, for example, concerning social or environmental issues. Here two relevant examples:

- Does forest certification really work? This study (Dasgupta \& Burivalova 2017) evaluates the effects of FSC certification in tropical forests separated into environmental, social and economic impacts. An interactive website allows the filtering of specific issues and distinguishes between stronger and weaker evidence regarding the impacts of FSC certification. 


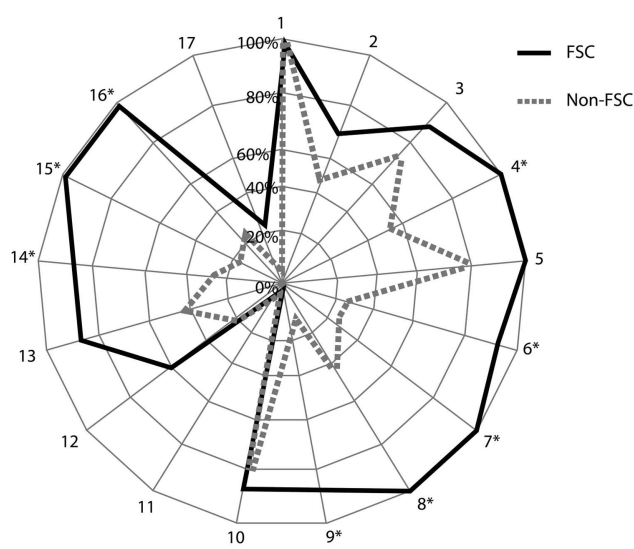

Cerutti et al. 2014: Variables related to working and living conditions

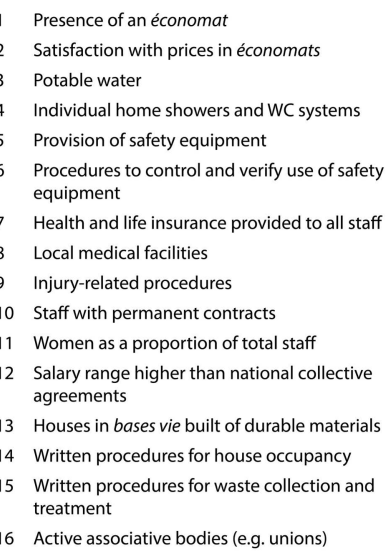

Figure 23.2 Variables related to working and living conditions.

The study clearly shows a significant positive impact on environmental and social questions through FSC certification.

- Social impacts of the Forest Stewardship Council certification: An assessment in the Congo basin. This study (Cerutti et al. 2014) compares FSC-certified with non-FSC-certified operations in central Africa in large areas. The results clearly show positive impacts on many social issues.

\section{The middle of the nexus: perceptions of consumers on sustainable production and labelled products}

Current sustainability labels are usually designed to address environmental and social issues around land use and the management of their commodities (i.e. timber from forests, soy/palm oil/cattle breeding from converted farmland, fish from fishery). Besides production aspects, new questions are arising and expected to be covered in environmentally friendly and socially fair labels such as regional sourcing or environmental and social standards in the following processing chain. An example of an existing consumer label already covering various of those aspects including sourcing, processing and health, is the German Blue Angel. The Blue Angel was founded to make environmentally friendly products visible to consumers. Issues touched by the Blue Angel for example with paper products are the use of recycling materials as well as many processing aspects like water pollution, water consumption, energy consumption, use of chemicals and health aspects.

Beyond those aspects, there are even more questions not addressed at all in current sustainability labels around general resource efficiency such as recyclability, efficient use of products, regional sourcing versus far transportation combined with life-cycle-assessments or general questions of the overall 
ecological $/ \mathrm{CO}_{2}$-footprint of the product. Some of those aspects may qualify for future labelling generations (i.e. recyclability, transport, $\mathrm{CO}_{2}$-footprint, transparency around life-cycle) while general consumption patterns may by concept not fit with the idea of labelling based on a consumer-driven concept.

NGOs and consumer organisations have over the years touched on some of those questions with conceptional approaches. As early as 2006, a process supported by 48 environmental organisations started phrasing a transformation process for the European paper industry. In 2014 the concept was expanded to a global paper vision formally supported by 108 environmental organisations worldwide (Environmental Paper Network 2014).

The vision phrases seven points for the use and the production of paper in a hierarchical order:

- $\quad$ reduce global paper consumption and promote fair access to paper;

- maximise recycled fibre content;

- $\quad$ ensure social responsibility;

- $\quad$ source fibre responsibly;

- $\quad$ reduce greenhouse gas emissions;

- ensure clean production; and

- $\quad$ ensure transparency and integrity.

The vision includes various opportunities for existing labels like the Blue Angel or FSC certified products. FSC is mentioned as a solution in 'sourcing fibre responsibly'. The vision shows that current expectations from the majority of environmental groups worldwide not only demand responsible sourcing and processing of products but also includes general questions on consumption patterns and personal behaviour beforehand. But even in this vision, a general concept of resource efficiency is not fully covered and addressed.

In the authors' view there is currently no satisfying answer that adequately addresses the responsible use of products including sourcing, processing, use and recycling with the question of consumption as such or an effective or 'wise' use of products in regards to the general challenge of overconsumption of global goods in a world of growing population. Further actions from all involved parties with a high responsibility for public policies and rules are needed.

\section{The certification dilemma}

As a demand-driven system, FSC relies to a large extent, and by concept, on the consumption of products. The more FSC products are sold and consumed, the higher the interest for market partners to demand more FSC certified materials with the effect of more certified forest area worldwide where FSC standards are implemented. This dynamic somehow 'releases' consumers from the responsibility to rethink existing consumption patterns. It also 'releases' 
retailers to reflect very generally the concept of 'selling of more products' or the underlying driving concept of economic growth. There is currently no guiding principles or legal safeguards in selling products with highly negative environmental or social impact. Examples for this is the sale of fresh fibrebased tissue paper, whereas recycling fibre-based tissue paper would be a more appropriate alternative. Similar aspects are concern around the packaging of products, recyclability of goods or effective use of primary products (durable products versus non-durable or throw-away-products).

Following this way of thinking, there is a big bundle of unaddressed questions going beyond the responsible production of goods. Particularly in times of a rapid climate change the following relevant aspects, most of them not touched and covered by sustainability labels like the FSC, include:

- general reduction of consumption;

- $\quad$ increased use of recycled products;

- avoidance of environmentally damaging products (examples for wooden products could be composite products based on wood fibres and plastic);

- transparency on environmental or social impacts on product;

- promoting products with longer life-cycles and reduction of on nonreturnable materials;

- considerations of cascading use of products;

- $\quad$ promotion and use of recyclable products; and

- reduction of unnecessary packaging and rethinking or packaging as such (including the replacement of plastic and environmentally unfriendly packaging to sustainable packaging or multiple uses of packaging).

NGOs observe a lack of coordinated approaches and the need for more broadly accepted definitions (i.e. on origin, life-cycle information, social and environmental impacts) and the urgent need for policy harmonisation at all levels of production and trade (i.e. policymakers, researchers, industry).

Within this situation, existing labels remain in the dilemma of delivering positive impacts in some production areas (i.e. FSC delivering products based on environmental and social standards in forestry) while not addressing major questions beyond production and sourcing (see above). As a consequence, the media and major NGOs carefully reflect on their support and their engagement in such systems. Some NGOs balance their work and invest in both (support for responsible primary production and sourcing as well as towards policy work for global consumption aspects) while others focus their engagement more on the broader issue of consumption and the life-cycle of products.

\section{Beyond the dilemma - discussion of possible solutions and recommendations}

It is very clear that a general call for less consumption, cascading use of products or alternative products (recycling, recyclability etc.) is at least not simple 
to touch on with existing tools if these are acting in isolation. It is also very clear that particularly the demand for less consumption is partly in contradiction to the demand-driven approach of labelling schemes. However, some labelling schemes are asking for a change of the management of, for example, land-use and that change could also work and go hand in hand with 'good management' and 'less consumption'.

For sustainability labels like FSC, a good way forward is not trivial. Key questions are if the system should expand its scope to broader sustainability aspects, through increasing complexity or if the systems should focus on its core competences at the risk of working in isolation of broader aspects of responsible consumption.

The authors do not want to give a ready-made answer both on the best way forward, nor on the most likely scenario in which sustainability labels will evolve in the upcoming years rather than contribute to a needed debate about the future role of sustainability labels. Regardless of the development of existing labels, it is very clear, that voluntary demand-driven consumer labels will not be able to touch on the question of consuming as such. Therefore the most likely scenario will be, that systems like FSC remain focussing mainly on the implementation of environmental and social standards in forestry worldwide. As a consequence, the dilemma can only be solved with intelligent combinations of various tools and the embedding of existing labelling systems like FSC in broader concepts. Here are some recommendations of processes to address the dilemma:

\section{Role for all}

Most of all modern societies, particularly, in the more developed part of the world, need to rethink their consumption patterns generally. We all need to act more environmentally and socially responsible and need to recognize the limits of the planet. By doing so, this automatically would require less consumption of everything (i.e. change in diet, change in mobility, change in energy consumption). Sustainability labels can only contribute in a positive way if consumption patterns as such are changing. Inhabitants of more developed countries with extremely higher consumption rates are much more in global responsibility than countries with high rates of poverty and low living standards.

This shift will need a fundamental change in personal attitude and behaviour. Parts of this can be done through voluntary and personal changes, the major part of this may require public incentives or legal safeguards.

A part of doing so would be a changed and more honest communication. 'Climate-friendly' has, for example, to be replaced by 'less climate-damaging' in cases where resources are used. Other examples are that 'more consumption of good products' is not necessarily 'better' compared with reduced consumption. Communication needs to be adjusted accordingly at all levels. To name things as they are is a way of taking responsibility and explaining their real picture. 


\section{Role of governments}

From the authors view the main reason is that a global shift towards less growth and an adjustment and reduction of consumption will have overall positive effects for the society because it can contribute to halting the climate crisis. However, individuals, particularly in more developed countries, could perceive this as adverse effects and would not be supportive pro-actively. As a consequence, individual and corporate behaviour in those areas can only be addressed through administrative actions and related legislations. Possible starting points could be:

- Changes in general frameworks: support of activities and programs need generally be evaluated against positive changes in social and environmental regards and not mainly based on economic considerations. This includes incentives for reduced consumption as well as incentives for more intelligent and efficient resource use (e.g. wood in construction rather than in the energy sector, support for cascading approaches in the use of products etc.).

- Consumption policies including hierarchical views for consumption and production rather than developing sector policies (example: incentives for cascading of products before using forest products directly in the energy sector).

- Tax-systems (i.e. $\mathrm{CO}_{2}$-taxes) favouring products along the line of responsible consumption.

- Support for sustainability labelling systems. 'Best in class' systems need clear advantages. Evaluations need to be done and published independently of political positions.

- Strict control, consequent and efficient implementation of existing policies already contributing to responsible production and consumption (i.e. EUTR, public procurement policies).

- Establishment of tools to seriously support and implement cascading of product uses.

- Active support of positive examples in responsible sourcing and responsible use of products (i.e. recycling, recyclable, cascading use).

- Public information campaigns about responsible production and responsible consumption at all levels.

- Leading by example to generate spillover effects.

- Shift to an ecological and socially responsible procurement as a legal requirement to operate in all public institutions (e.g. ministries, schools, universities).

\section{Role of the corporate sector}

Companies need to adjust products and behaviour to the modern needs of the globe. This goes beyond cost-considerations. 
On the product side, need to work on more sustainable products beyond responsible sourcing, including aspects such as recyclability of products, a conceptional shift from non-returnable products to long-living products, reducing packaging, $\mathrm{CO}_{2}$-considerations, among others.

Beyond products, companies need to rethink and adjust sustainability behaviour at all levels of their footprints, including, procurement, mobility, energy, water, among others.

\section{Role of the media}

Much more than in the past, the media needs to shed light on the views of the sectors in the context of the overall picture of responsible production and responsible consumption. A growing role in this regard could be to call out companies not properly delivering on their goals and not behaving accountable. Moreover, to support opinion-building with clear, fact-based honest and frank communication.

\section{Role of NGOs}

NGOs could have two roles in this change. On the one hand, there is a consequent need for information on existing labels and on a hierarchical view on consumption (as for example stated in the global paper vision). There is a need for a global 'consumption vision' or 'global product vision' including aspects of reduction, recycling, sourcing, recyclability, cascading, life-cycle etc.. The second role for NGOs is to remain a pressure group towards public authorities, governments and companies to push this change.

\section{Role of existing sustainability labels}

Certification systems need to continually evaluate their role in supporting responsible production, processing and trade. At the same time the alliance of sustainability labels needs to continually reflect whether it can contribute in positive ways at the level of overall consumption through mutual communication and strategic exchange with the global retail sector.

Further developments of existing labels should always evaluate if current society (means stakeholder and interest groups) needs are incorporated in technical solutions and if relevant stakeholder groups do support existing solutions and contents of the relevant system.

\section{Abbreviations}

COC chain of custody

CR Corporate responsibilty

CW controlled wood

EUTR European Timber Regulation 
FPIC free prior informed consent

FSC Forest Stewardship Council

HCV high conservation value

IG BAU Industiergewertschaft Bauen Agrar Umwelt

IG Metall Industriegewerkschaft Metall

ILO International Labour Organization

NABU Naturschutzbund Deutschland

NGO non-governmental organization

WWF World Wide Fund for Nature

\section{References}

Cerutti, P. O., Lescuyer, G., Tsanga, R., Kassa, S. N., Mapangou, P. R., Mendoula, E. E., Missamba-Lola, A. P., Nasi, R., Eckebil, P. P. T., and Yembe, R. Y. (2014). Social impacts of the Forest Stewardship Council certification: An assessment in the Congo basin. Occasional Paper 103. CIFOR, Bogor, Indonesia. URL: https://cifor.org/library/ 4487/ (09.09.2019).

Dasgupta, S. and Burivalova, Z. (2017). URL: https://news.mongabay.com/2017/09/ does-forest-certification-really-work/ (09.09.2019).

EDEKA (2019). Nachhaltige Waldwirtschaft, EDEKA. URL: www.edeka.de/nachhaltigkeit/ unsere-wwf-partnerschaft/holz-paper-tissue/index.jsp (12.09.2019).

Environmental Paper Network (2014). The Global Paper Vision. URL: https:// environmentalpaper.org/epn-vision/vision/ (12.09.2019).

FSC (2017). Requirements for Sourcing FSC Controlled Wood FSC-STD-40-005 V3-1 EN. URL: https://fsc.org/en/document-center/documents/170 (06.09.2019).

IKEA (2018). Materialien \& Rohstoffe bei IKEA. URL: www.ikea.com/de/de/this-is-ikea/ sustainable-everyday/materialien-und-rohstoffe-bei-ikea-pub971c9d11\# Holz\%20ist \%20der\%20Kern\%20von\%20IKEA (12.09.2019).

ILO (n.d.). ILO Conventions and Recommendations. URL: https://ilo.org/global/standards/ introduction-to-international-labour-standards/conventions-and-recommendations/ lang--en/index.htm (06.09.2019).

Lidl Deutschland (2018). Positionspapierfür den nachhaltigeren Einkauf von zellulose-haltigen Eigenmarken-produkten und Verpackungen. URL: www.lidl.de/de/asset/other/16201_ FLY_Positionspapier_Zellulose_A4_DE_2_online.pdf (12.9.2019).

Otto Group (2019). Geschäftsbericht 2018/2019 Otto Group. URL: https://ottogroup. com/media/docs/de/geschaeftsbericht/Otto_Group_Geschaeftsbericht_2018_19_DE. pdf (12.09.2019).

Strasser, M. and Litschel, J. (2017). FSC Forstbetriebe unter der Lupe; AFZ-DerWald 2/2017.

United Nations (2013). Free, Prior and Informed Consent of Indigenous Peoples. URL: www. ohchr.org/Documents/Issues/ipeoples/freepriorandinformedconsent.pdf (06.09.2019). 